\title{
Variability of fish consumption within the 10 European countries participating in the European Investigation into Cancer and Nutrition (EPIC) study
}

\author{
AA Welch ${ }^{1, *}$, E Lund $^{2}$, P Amiano $^{3}$, M Dorronsoro $^{3}, \mathrm{M} \mathrm{Brustad}^{2}, \mathrm{M} \mathrm{Kumle}^{2}, \mathrm{M} \mathrm{Rodriguez}^{4}$,

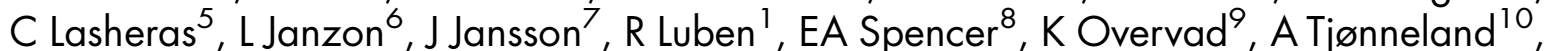 \\ F Clavel-Chapelon $^{11}$, J Linseisen ${ }^{12}$, K Klipstein-Grobusch ${ }^{13}$, V Benetou ${ }^{14}$, X Zavitsanos ${ }^{14}$, \\ $\mathrm{R}_{\text {Tumino }}{ }^{15}$, R Galasso ${ }^{16}$, HB Bueno-de-Mesquita ${ }^{17}, \mathrm{MC} \mathrm{Ocké}^{17}$, UR Charrondière ${ }^{18}$ and \\ N Slimani ${ }^{18}$ \\ 'Strangeways Research Laboratory, Department of Public Health and Primary Care, University of Cambridge, Wort's \\ Causeway, Cambridge CB1 8RN, UK: ${ }^{2}$ Institute of Community Medicine, University of Tromsø, Norway: ${ }^{3}$ Public \\ Health Division of Gipuzkoa, Department of Health of the Basque Government, San Sebastian, Spain: ${ }^{4}$ Granada \\ Cancer Registry, Andalusian School of Public Health, Granada, Spain: ${ }^{5}$ Department of Functional Biology, Faculty of \\ Medicine, University of Oviedo, Spain: ${ }^{6}$ Department of Community Medicine, Malmö University Hospital, Sweden: \\ ${ }^{7}$ Reseach Centre for Endocrinology and Metabolism, Sahlgrenska University Hospital, Göteborg, Sweden: ${ }^{8}$ Cancer \\ Research UK, Epidemiology Unit, University of Oxford, UK: ${ }^{9}$ Department of Epidemiology and Social Medicine, \\ University of Aarhus, Denmark: ${ }^{10}$ Institute of Cancer Epidemiology, Danish Cancer Society, Copenhagen, Denmark: \\ ${ }^{11}$ INSERM, E3N-EPIC Group, Institute Gustave Roussy, Villejuif, France: ${ }^{12}$ Division of Clinical Epidemiology, \\ German Cancer Research Centre, Heidelberg, Germany: ${ }^{13}$ Department of Epidemiology, German Institute of Human \\ Nutrition, Potsdam-Rehbrücke, Germany: ${ }^{14}$ Department of Hygiene and Epidemiology, School of Medicine, \\ University of Athens, Greece: ${ }^{15}$ Cancer Registry, 'Civile - M.P. Arezzo' Hospital, Ragusa, Italy: ${ }^{16}$ Institute of Internal \\ Medicine and Metabolic Diseases, University of Naples, Italy: ${ }^{17}$ Department of Chronic Diseases Epidemiology, \\ National Institute for Public Health and the Environment, Bilthoven, The Netherlands: ${ }^{18}$ International Agency for \\ Research on Cancer, Lyon, France
}

\begin{abstract}
Objective: To describe and compare the consumption of total fish (marine foods) and the fish sub-groups - white fish, fatty fish, very fatty fish, fish products and crustacea, in participants from the European Investigation into Cancer and Nutrition (EPIC) study.

Design: Cross-sectional analysis of dietary intake using a computerised standardised 24-hour recall interview. Crude means, means and standard errors adjusted by age, season and day of the week were calculated, stratified by centre and gender. Setting: Twenty-seven redefined centres in the 10 European countries participating in the EPIC study.

Subjects: In total, 35955 subjects (13031 men and 22924 women), aged 35-74 years, selected from the main EPIC cohort.

Results: A six- to sevenfold variation in total fish consumption exists in women and men, between the lowest consumption in Germany and the highest in Spain. Overall, white fish represented $49 \%$ and $45 \%$ of the intake of total fish in women and men, respectively, with the greatest consumption in centres in Spain and Greece and the least in the German and Dutch centres. Consumption of fatty fish reflected that of total fish. However, the greatest intake of very fatty fish was in the coastal areas of northern Europe (Denmark, Sweden and Norway) and in Germany. Consumption of fish products was greater in northern than in southern Europe, with white fish products predominating in centres in France, Italy, Spain, The Netherlands and Norway. Intake of roe and roe products was low. The highest consumption of crustacea was found in the French, Spanish and Italian centres. The number of fish types consumed was greater in southern than in northern Europe. The greatest variability in consumption by day of the week was found in the countries with the lowest fish intake.

Conclusions: Throughout Europe, substantial geographic variation exists in total fish intake, fish sub-groups and the number of types consumed. Day-to-day variability in consumption is also high.
\end{abstract}

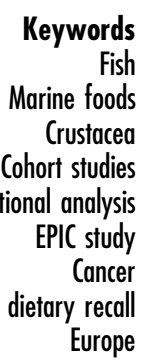


Consumption of fish (including all marine seafood) may be important in the aetiology of disease. Reviews of the evidence relating diet and cancer, by the World Cancer Research Fund (WCRF) and American Institute for Cancer Research (AICR) in 1997 and the UK Committee on Medical Aspects of Food and Nutrition (COMA) in 1998, found insufficient data on fish consumption to draw conclusions for cancers of the breast, lung, prostate, pancreas, oesophagus, ovary, endometrium, liver, larynx, bladder and kidney ${ }^{1,2}$. Both of these reports found moderately consistent evidence that fish was not associated with colorectal cancer and some moderately consistent evidence that high intakes of salted meat and fish were associated with gastric cancer. The WCRF/AICR report stated that there was convincing evidence that salted fish increases the risk of nasopharyngeal cancer ${ }^{1}$. The International Agency for Research on Cancer (IARC) had earlier concluded that Chinese salted fish is carcinogenic to humans ${ }^{3}$.

Since these early reports, evidence has become available from ecological, case-control and prospective studies indicating that the consumption of fish may be protective for cancers of the prostate, breast, colon and other parts of the digestive tract ${ }^{4-8}$. There is also good evidence for a protective effect of consumption of fish in cardiovascular disease ${ }^{9-15}$, although this is probably limited to high-risk populations ${ }^{10}$.

Fish are important sources of a number of nutrients, particularly protein, retinol, vitamin $\mathrm{D}$, vitamin $\mathrm{E}$, iodine, selenium and the essential long-chain $n-3$ polyunsaturated fatty acids (PUFA) $-\alpha$-linolenic acid $(18: 3 n-3)$, eicosapentaenoic acid (20:5n-3, EPA) and docosahexaenoic acid (22:6n-3, DHA). Fish are the main source of intake of these fatty acids, although they can be obtained via the metabolic conversion of the $\alpha$-linolenic acid present in oils such as canola (rapeseed), soya, linseed and walnut $^{16}$.

The fat content of fish varies from $1.0 \mathrm{~g} / 100 \mathrm{~g}$ in white fish to $30 \mathrm{~g} / 100 \mathrm{~g}$ in fatty fish ${ }^{17}$. It also varies within the breeding cycle ${ }^{18}$. The content of $n-3$ PUFA varies accordingly from $0.48 \mathrm{~g} / 100 \mathrm{~g}$ in white fish (cod) to $0.68 \mathrm{~g} / 100 \mathrm{~g}$ in crustacea (mussels) to $0.98 \mathrm{~g} / 100 \mathrm{~g}$ in roe and $5.33 \mathrm{~g} / 100 \mathrm{~g}$ in fatty fish (mackerel) ${ }^{19}$. Although the absolute amount of $n-3$ PUFA is lower in white fish, it represents a higher proportion of total fat than in fatty fish: $37 \%$ vs. $17 \%$. Biomarkers of $n-3$ PUFA measured in serum, plasma and adipose tissue corroborate intake of fish ${ }^{20-29}$ and are positively associated within particular fatty fish (Saadatian-Elahi, in preparation).

However, until now, the study of fish intake has largely been within single countries and has not been able to use the full heterogeneity of intake in Europe. Many studies have made no distinction between consumption of white and fatty fish, yet intake of fatty fish predicts plasma levels of $n-3$ PUFA better than intake of white fish ${ }^{27}$. Methods used by other studies to assess intake of fish range from estimates of sales statistics by the Food and Agriculture Organization (FAO) to individual dietary methods. We are not aware of any large population study using standardised techniques to estimate individual intakes of different types of fish that addresses the substantial variation in nutritional composition of fish across a range of European countries.

The purpose of this study was to investigate variability in the consumption of types of fish across the 10 European countries participating in the European Investigation into Cancer and Nutrition (EPIC) study.

\section{Methods}

\section{Population and study sample}

EPIC is a study of nutrition, lifestyle and other environmental factors and cancer in 519978 men and women in 23 administrative centres of 10 countries throughout Europe ${ }^{30}$. The baseline data collection, carried out between 1992 and 2000, included a main dietary questionnaire, anthropometric measurements and collection of blood. A calibration study was performed to provide a reference measure of dietary intake for the main dietary questionnaire and this analysis was based on these data. The calibration study used in the analysis included 36900 subjects and, after exclusions, resulted in a sample of 35955 men and women aged between 35 and 74 years (22924 women and 13031 men). The sample was designed to be a stratified random sample from the main cohort and included between $1.5 \%$ and $12 \%$ of the main study population in each country. It was designed to sample equally from all seasons and days of the week and represent intake at the population level. In France and Norway, Utrecht (The Netherlands) and Naples (Italy) only women were recruited. The aims and details of the main and calibration study populations and their characteristics are given in elsewhere in this supplement $^{30,31}$.

For the purposes of this study of diet, the 23 initial study centres were redefined into 27 centres, largely on a geographical basis. The term 'centre' refers to either a data collection centre or a region. France was divided into four regions, the North-east, North-west, South and South coast. In the UK, those recruited via general practitioners from the general population by the Oxford and Cambridge centres were separated from those recruited by Oxford by post from a 'health-conscious' population. The 'healthconscious' group includes a large number of individuals following vegan, vegetarian and fish-eating diets, and contains a small proportion of meat eaters. In Norway, the study cohorts were sub-divided into coastal (North \& West) and inland (South \& East) regions. The centre referred to as Bilthoven includes populations recruited from the areas of Amsterdam, Doetinchem and Maastricht in The Netherlands. 


\section{Dietary metbod}

The reference measure was a 24-hour recall performed using specifically designed software (the EPIC-SOFT program $)^{32}$. This was developed at IARC in collaboration with all study centres to standardise the method, content and structure of the interview and supporting databases for portion size estimates ${ }^{32,33}$. Methods of estimation of portion size were standardised between countries and included photographs, household measures and standard units. Estimates of consumption excluded waste material and the factors used to calculate wastage were standardised. This is particularly important for fish where the proportion of wastage is variable and can amount to $60 \%$ of the original item. Fish contained within mixed recipes was separated from the other ingredients and included in the total estimates of fish and its sub-groups. This differs from most other systems, which include the other ingredients of mixed recipes within food group estimates.

Interviewers were trained with a standardised method of approach to avoid bias within and between centres ${ }^{33}$. The period of recall was from waking to sleeping during the previous 24 hours. As there were some logistical difficulties in interviewing over weekend days, some recalls were performed for a maximum of 48 hours previously.

\section{Classification offish sub-groups}

The food group classifications available were 'fish', 'fish products' and 'crustacea'. A few items, containing fish, had also been classified as 'snacks' and were included in these analyses. In order to classify fish according to their fat content, sub-divisions were devised based on traditional categories and the fat content of raw fish (per $100 \mathrm{~g}$ of edible part $)^{17}$. Fish were classified as 'white fish' such as cod, haddock and plaice (fat up to $4 \mathrm{~g} / 100 \mathrm{~g}$ ) or 'total fatty fish' (fat equal to or greater than $4 \mathrm{~g} / 100 \mathrm{~g}$ ). Total fatty fish were further sub-divided into 'fatty fish' such as salmon, tuna and trout (fat between $4 \mathrm{~g} / 100 \mathrm{~g}$ and $14 \mathrm{~g} / 100 \mathrm{~g}$ ) and 'very fatty fish' such as herring, kippers and mackerel (fat $14 \mathrm{~g} / 100 \mathrm{~g}$ or more). Roe and roe products were classified into a separate group. The classification of fish products included items coated in batter, breadcrumbs or pastry, roe and roe products, and fermented dried fish. Fish products were also divided into 'white fish products', 'fatty fish products' and 'roe-based products'. The group referred to as crustacea throughout this paper also includes molluscs. The variable 'all fish and fish products' includes all fish, crustacea and fish products and is referred to as 'total fish' throughout the following text and tables. For a schematic view of the fish subgroups, see Fig. 1.

Another classification into types of fish was made using the common name of fish reported in each country. Items from the groups 'fish' and 'fish products' were included. Within the fish products group, fermented, smoked and dried fish were included but all other products containing additional ingredients such as bread, fat, flour or sauce were excluded. Where it was considered that names would be used interchangeably, e.g. hake and burbot, they were combined into one category. The total weight of each type of fish was calculated as the percentage contribution to total fish intake, by country.

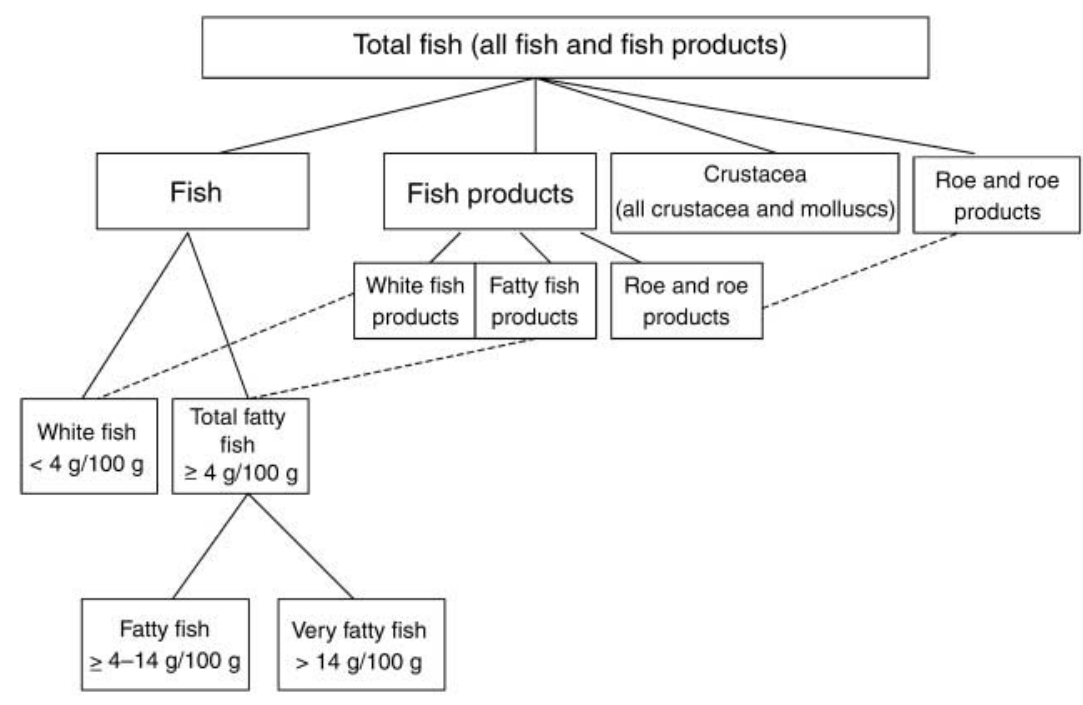

Independent fractions of sub-groups

Sub-group included in more than one group

Fig. 1 Schematic view of the relationship between fish sub-groups 
Table 1a Mean daily intake $\left(\mathrm{g} \mathrm{day}^{-1}\right.$ ) of all fish and fish products, white fish and crustacea in women

\begin{tabular}{|c|c|c|c|c|c|c|c|c|c|c|c|c|c|}
\hline \multirow[b]{3}{*}{ Country and centre } & \multirow[b]{3}{*}{$n$} & \multicolumn{4}{|c|}{ Fish and fish products (total) } & \multicolumn{4}{|c|}{ White fish } & \multicolumn{4}{|c|}{ Crustacea } \\
\hline & & \multirow{2}{*}{$\begin{array}{c}\% \\
\text { Reporters }\end{array}$} & \multirow{2}{*}{$\begin{array}{l}\text { Crude } \\
\text { mean }\end{array}$} & \multicolumn{2}{|c|}{ Adjusted } & \multirow{2}{*}{$\begin{array}{l}\text { Crude } \\
\text { mean }\end{array}$} & \multicolumn{2}{|c|}{ Adjusted } & \multirow{2}{*}{$\begin{array}{l}\% \text { White } \\
\text { fish† }\end{array}$} & \multirow{2}{*}{$\begin{array}{l}\text { Crude } \\
\text { mean }\end{array}$} & \multicolumn{2}{|c|}{ Adjusted } & \multirow{2}{*}{$\begin{array}{c}\% \\
\text { Crustacea† }\end{array}$} \\
\hline & & & & Mean ${ }^{*}$ & SE & & Mean* & SE & & & Mean* & SE & \\
\hline Greece & 1374 & & & & & & & & & & & & \\
\hline Greece & 1374 & 24.3 & 31.8 & 30.8 & 1.7 & 18.2 & 16.6 & 1.3 & 57.2 & 4.1 & 4.7 & 0.5 & 12.9 \\
\hline Spain & 1443 & & & & & & & & & & & & \\
\hline Granada & 300 & 56.0 & 53.3 & 55.1 & 3.6 & 26.4 & 25.5 & 2.8 & 49.5 & 9.6 & 10.8 & 1.1 & 18.0 \\
\hline Murcia & 304 & 58.2 & 50.6 & 50.9 & 3.6 & 27.1 & 27.5 & 2.8 & 53.6 & 5.4 & 5.3 & 1.1 & 10.7 \\
\hline Navarra & 271 & 56.5 & 65.7 & 65.3 & 3.8 & 39.9 & 40.8 & 3.0 & 60.7 & 6.8 & 6.1 & 1.2 & 10.4 \\
\hline San Sebastian & 244 & 57.0 & 73.5 & 72.0 & 4.0 & 46.2 & 47.1 & 3.1 & 62.9 & 7.0 & 6.5 & 1.2 & 9.5 \\
\hline Asturias & 324 & 55.6 & 68.4 & 67.8 & 3.5 & 39.1 & 39.8 & 2.7 & 57.2 & 6.4 & 5.7 & 1.1 & 9.4 \\
\hline Italy & 2512 & & & & & & & & & & & & \\
\hline Ragusa & 138 & 21.7 & 30.9 & 32.1 & 5.4 & 10.3 & 10.3 & 4.2 & 33.3 & 5.9 & 4.7 & 1.6 & 19.1 \\
\hline Naples & 403 & 26.8 & 28.0 & 26.3 & 3.1 & 16.3 & 13.6 & 2.4 & 58.2 & 3.3 & 3.9 & 0.9 & 11.8 \\
\hline Florence & 785 & 21.7 & 19.8 & 20.4 & 2.3 & 10.4 & 11.0 & 1.7 & 52.5 & 2.8 & 2.8 & 0.7 & 14.1 \\
\hline Turin & 392 & 25.5 & 20.6 & 21.1 & 3.2 & 10.1 & 10.0 & 2.5 & 49.0 & 1.9 & 2.2 & 1.0 & 9.2 \\
\hline Varese & 794 & 20.4 & 19.9 & 18.3 & 2.2 & 7.1 & 6.8 & 1.7 & 35.7 & 3.1 & 2.7 & 0.7 & 15.6 \\
\hline France & 4639 & & & & & & & & & & & & \\
\hline South coast & 612 & 38.6 & 38.3 & 40.4 & 2.6 & 21.9 & 22.2 & 2.0 & 57.2 & 5.9 & 6.2 & 0.8 & 15.4 \\
\hline South & 1396 & 33.7 & 35.3 & 35.0 & 1.7 & 20.6 & 20.8 & 1.3 & 58.4 & 4.3 & 4.4 & 0.5 & 12.2 \\
\hline North-west & 622 & 45.8 & 50.6 & 52.4 & 2.5 & 27.9 & 28.4 & 2.0 & 55.1 & 10.9 & 12.5 & 0.8 & 21.5 \\
\hline North-east & 2009 & 35.0 & 37.0 & 38.0 & 1.4 & 20.8 & 21.4 & 1.1 & 56.2 & 4.8 & 5.1 & 0.4 & 13.0 \\
\hline Germany & 2150 & & & & & & & & & & & & \\
\hline Heidelberg & 1087 & 12.3 & 13.2 & 15.9 & 1.9 & 5.6 & 6.8 & 1.5 & 42.4 & 1.0 & 1.4 & 0.6 & 7.6 \\
\hline Potsdam & 1063 & 17.8 & 17.9 & 19.9 & 1.9 & 7.1 & 7.6 & 1.5 & 39.7 & 0.1 & 0.1 & 0.6 & 0.6 \\
\hline The Netherlands & 2960 & & & & & & & & & & & & \\
\hline Bilthoven & 1086 & 15.1 & 12.6 & 13.3 & 2.0 & 5.0 & 5.7 & 1.5 & 39.7 & 1.6 & 1.4 & 0.6 & 12.7 \\
\hline Utrecht & 1874 & 14.3 & 14.8 & 13.4 & 1.5 & 6.9 & 6.2 & 1.1 & 46.6 & 0.9 & 0.8 & 0.4 & 6.1 \\
\hline United Kingdom & 768 & & & & & & & & & & & & \\
\hline General population & 571 & 30.5 & 28.3 & 28.7 & 2.6 & 15.7 & 15.8 & 2.0 & 55.5 & 2.2 & 2.4 & 0.8 & 7.8 \\
\hline 'Health-conscious' & 197 & 17.8 & 15.8 & 14.3 & 4.5 & 6.0 & 6.1 & 3.5 & 38.0 & 1.0 & 0.6 & 1.4 & 6.3 \\
\hline Denmark & 1995 & & & & & & & & & & & & \\
\hline Copenhagen & 1485 & 42.1 & 37.2 & 37.3 & 1.6 & 14.9 & 14.2 & 1.3 & 40.1 & 3.0 & 3.1 & 0.5 & 8.1 \\
\hline Aarhus & 510 & 40.4 & 31.4 & 31.1 & 2.8 & 11.3 & 10.4 & 2.2 & 36.0 & 2.8 & 3.4 & 0.8 & 8.9 \\
\hline Sweden & 3285 & & & & & & & & & & & & \\
\hline Malmö & 1711 & 37.5 & 33.8 & 32.1 & 1.6 & 14.9 & 13.7 & 1.2 & 44.1 & 3.1 & 3.0 & 0.5 & 9.2 \\
\hline Umeå & 1574 & 36.1 & 28.8 & 27.7 & 1.6 & 9.7 & 10.2 & 1.2 & 33.7 & 2.6 & 2.3 & 0.5 & 9.0 \\
\hline Norway & 1798 & & & & & & & & & & & & \\
\hline South \& East & 1136 & 43.3 & 41.2 & 42.9 & 1.9 & 22.1 & 22.9 & 1.5 & 53.6 & 3.9 & 4.3 & 0.6 & 9.5 \\
\hline North \& West & 662 & 49.4 & 61.1 & 63.3 & 2.5 & 40.4 & 42.2 & 1.9 & 66.1 & 3.3 & 3.1 & 0.7 & 5.4 \\
\hline
\end{tabular}

SE - standard error.

*Adjusted for age, weighted for season and day of the week.

†Percentage of all fish and fish products (crude mean).

\section{Statistical methods}

Crude means, adjusted means and standard errors were calculated for fish sub-groups and stratified by gender and centre. The design of the calibration study was over the period of 1 year, so that each season was represented by $25 \%$ of participants and each day of the week by $14.2 \%$ of participants. Practical limitations meant this was not completely achieved ${ }^{31}$ and to account for these variations in sampling procedures, adjusted means and standard errors were calculated by the analysis of covariance technique using weighting factors for season and day of the week. (Weights were calculated as the ratio between the expected frequency under ideal conditions and the actual frequency.) To adjust for the different age distribution in the calibration sub-populations, age at time of interview was used as a continuous variable. A further analysis assessed the impact of energy intake, derived from the 24-hour recall, which was added to the model as a continuous variable.

Day-to-day variation in fish consumption was investigated and unadjusted means are presented for individual countries. The UK 'health-conscious' group was excluded, as there were fewer than five records for some days of the week.

Adjusted means were calculated using general linear models (GLM) in SAS version 6.12 (SAS Institute, Inc., Cary, NC, USA). The remaining analyses were performed using STATA version 7.0 (Stata Corp., College Station, TX, USA).

\section{Results}

\section{Fish sub-groups}

There was considerable variation in the consumption of total fish and other sub-groups, as shown in Tables 1a-3b. 
Table 1b Mean daily intake $\left(\mathrm{g} \mathrm{day}^{-1}\right.$ ) of all fish and fish products, white fish and crustacea in men

\begin{tabular}{|c|c|c|c|c|c|c|c|c|c|c|c|c|c|}
\hline \multirow[b]{3}{*}{ Country and centre } & \multirow[b]{3}{*}{$n$} & \multicolumn{4}{|c|}{ Fish and fish products (total) } & \multicolumn{4}{|c|}{ White fish } & \multicolumn{4}{|c|}{ Crustacea } \\
\hline & & \multirow{2}{*}{$\begin{array}{c}\% \\
\text { Reporters }\end{array}$} & \multirow{2}{*}{$\begin{array}{l}\text { Crude } \\
\text { mean }\end{array}$} & \multicolumn{2}{|c|}{ Adjusted } & \multirow{2}{*}{$\begin{array}{l}\text { Crude } \\
\text { mean }\end{array}$} & \multicolumn{2}{|c|}{ Adjusted } & \multirow{2}{*}{$\begin{array}{l}\% \text { White } \\
\text { fish† }\end{array}$} & \multirow{2}{*}{$\begin{array}{l}\text { Crude } \\
\text { mean }\end{array}$} & \multicolumn{2}{|c|}{ Adjusted } & \multirow{2}{*}{$\begin{array}{c}\% \\
\text { Crustaceat }\end{array}$} \\
\hline & & & & Mean $^{*}$ & SE & & Mean* $^{*}$ & SE & & & Mean* & SE & \\
\hline Greece & 1312 & & & & & & & & & & & & \\
\hline Greece & 1312 & 27.8 & 46.0 & 52.4 & 2.3 & 24.2 & 27.4 & 1.8 & 52.6 & 5.1 & 5.7 & 0.6 & 11.1 \\
\hline Spain & 1777 & & & & & & & & & & & & \\
\hline Granada & 214 & 64.5 & 87.1 & 85.6 & 5.6 & 53.3 & 49.9 & 4.3 & 61.2 & 10.5 & 12.5 & 1.6 & 12.1 \\
\hline Murcia & 243 & 62.1 & 70.1 & 65.1 & 5.3 & 34.9 & 32.2 & 4.1 & 49.8 & 11.3 & 8.8 & 1.5 & 16.1 \\
\hline Navarra & 444 & 58.1 & 84.1 & 83.2 & 3.9 & 45.4 & 45.1 & 3.0 & 54.0 & 11.1 & 10.8 & 1.1 & 13.2 \\
\hline San Sebastian & 490 & 60.2 & 121.6 & 120.1 & 3.8 & 81.5 & 82.6 & 2.9 & 67.0 & 6.0 & 5.4 & 1.0 & 4.9 \\
\hline Asturias & 386 & 65.0 & 104.4 & 104.2 & 4.2 & 48.2 & 46.8 & 3.2 & 46.2 & 15.1 & 14.8 & 1.2 & 14.5 \\
\hline Italy & 1444 & & & & & & & & & & & & \\
\hline Ragusa & 168 & 20.8 & 34.1 & 28.2 & 6.4 & 14.3 & 12.5 & 4.9 & 41.9 & 8.1 & 6.3 & 1.8 & 23.8 \\
\hline Florence & 271 & 28.8 & 35.3 & 37.0 & 5.0 & 15.4 & 16.3 & 3.8 & 43.6 & 7.8 & 9.8 & 1.4 & 22.1 \\
\hline Turin & 677 & 31.8 & 34.7 & 34.4 & 3.2 & 14.4 & 14.3 & 2.4 & 41.5 & 4.8 & 4.2 & 0.9 & 13.8 \\
\hline Varese & 328 & 18.9 & 25.6 & 19.7 & 4.5 & 11.3 & 9.2 & 3.5 & 44.1 & 2.3 & 1.4 & 1.3 & 9.0 \\
\hline Germany & 2268 & & & & & & & & & & & & \\
\hline Heidelberg & 1033 & 12.5 & 16.1 & 16.9 & 2.6 & 4.9 & 5.2 & 2.0 & 30.4 & 1.3 & 1.1 & 0.7 & 8.1 \\
\hline Potsdam & 1235 & 19.0 & 23.7 & 24.0 & 2.3 & 6.7 & 6.5 & 1.8 & 28.3 & 0.3 & 0.3 & 0.6 & 1.3 \\
\hline The Netherlands & 1024 & & & & & & & & & & & & \\
\hline Bilthoven & 1024 & 14.9 & 17.9 & 17.6 & 2.7 & 7.3 & 8.0 & 2.0 & 40.8 & 2.3 & 1.7 & 0.7 & 12.8 \\
\hline United Kingdom & 518 & & & & & & & & & & & & \\
\hline General population & 404 & 28.7 & 33.8 & 33.3 & 4.1 & 16.8 & 16.5 & 3.2 & 49.7 & 2.6 & 2.9 & 1.1 & 7.7 \\
\hline 'Health-conscious' & 114 & 7.9 & 6.4 & 7.4 & 7.7 & 3.3 & 3.5 & 5.9 & 51.6 & 0.1 & $\ddagger$ & 2.1 & 1.6 \\
\hline Denmark & 1923 & & & & & & & & & & & & \\
\hline Copenhagen & 1356 & 45.3 & 47.6 & 45.7 & 2.2 & 17.5 & 15.7 & 1.7 & 36.8 & 4.2 & 4.4 & 0.6 & 8.8 \\
\hline Aarhus & 567 & 40.4 & 44.4 & 44.0 & 3.5 & 18.8 & 17.5 & 2.7 & 42.3 & 2.2 & 2.9 & 1.0 & 5.0 \\
\hline Sweden & 2765 & & & & & & & & & & & & \\
\hline Malmö & 1421 & 38.1 & 41.9 & 41.9 & 2.3 & 19.9 & 20.3 & 1.8 & 47.5 & 3.3 & 3.9 & 0.6 & 7.9 \\
\hline Umeå & 1344 & 35.1 & 33.8 & 32.6 & 2.2 & 11.2 & 10.7 & 1.7 & 33.1 & 2.2 & 2.4 & 0.6 & 6.5 \\
\hline
\end{tabular}

SE - standard error.

${ }^{*}$ Adjusted for age, weighted for season and day of the week.

† Percentage of all fish and fish products (crude mean).

$\ddagger$ Adjusted mean omitted due to negative value.

There were also substantial differences between countries in the percentage of days on which individuals reported fish, which varied from $12.3 \%$ in Heidelberg, Germany (women) to $65 \%$ in Asturias, Spain (men). The variation in the percentage of days on which fish was reported generally followed the same trends as total fish consumption.

Populations with similar levels of fish intake were clustered in areas with similar coastal access, probably reflecting traditional styles of eating in these areas (Tables $1 \mathrm{a}$ and 1b). In men, high fish intakes were found in the Spanish, Greek and Danish centres and in Malmö (Sweden). In addition to these areas, for women, the highest intakes were found in the Norwegian and French centres, particularly the coastal area of North-west France and the North \& West of Norway. The lowest total fish consumption for both women and men was found in the UK 'health-conscious', Bilthoven (The Netherlands) and the German centres and, in women only, in Utrecht (The Netherlands). Intakes ranged by a factor of 5.8 in women and 7.6 in men.

Adjustment of mean values by age, season and day of the week resulted in values that were generally similar to unadjusted values with the exception of men in Greece, where an increase of $6.3 \mathrm{~g}$, from $46.0 \mathrm{~g}$ to $52.3 \mathrm{~g}$, resulted, a
$12 \%$ change. In Varese and Ragusa (Italy) decreases of $5.9 \mathrm{~g}$ occurred, representing $29.7 \%$ and $20.7 \%$, respectively. In women, absolute differences ranged from $0.1 \mathrm{~g}$ to $2.7 \mathrm{~g}$, representing differences of $0.2 \%$ in Copenhagen (Denmark) and 16.8\% in Heidelberg (Germany).

Additional adjustment for energy (not shown) produced differences in means that were similar to adjustment by age, season and day of the week, with only the exception of a $37 \%$ difference for UK 'health-conscious' males. Otherwise the difference was a maximum of $12 \%$ for women from Greece and 7\% for men.

In men, the greatest quantities of white fish were consumed in the Spanish centres and Greece and the least in the UK 'health-conscious' group and the German and Dutch centres (see Tables $1 \mathrm{a}$ and $1 \mathrm{~b}$ ). In women, greater consumption occurred in the Spanish, Norwegian and French centres and the least in the UK 'health-conscious' and the German, Italian and Dutch centres. The average consumption of white fish (as a percentage of total fish) was $49 \%$ in women and varied from $33.3 \%$ in Ragusa (Italy) to $66.1 \%$ in North \& West Norway. In men, the average percentage of white fish was $45 \%$ and varied from $28.3 \%$ in Potsdam (Germany) to 67\% in San Sebastian (Spain).

The quantity of crustacea consumed was much smaller 
Table 2a Mean daily intake $\left(\mathrm{g} \mathrm{day}^{-1}\right)$ of total fatty fish, fatty fish and very fatty fish in women

\begin{tabular}{|c|c|c|c|c|c|c|c|c|c|c|c|c|c|}
\hline \multirow[b]{3}{*}{ Country and centre } & \multirow[b]{3}{*}{$n$} & \multicolumn{4}{|c|}{ Total fatty fish } & \multicolumn{4}{|c|}{ Fatty fish } & \multicolumn{4}{|c|}{ Very fatty fish } \\
\hline & & \multirow{2}{*}{$\begin{array}{l}\text { Crude } \\
\text { mean }\end{array}$} & \multicolumn{2}{|c|}{ Adjusted } & \multirow{2}{*}{$\begin{array}{l}\% \text { Fatty } \\
\text { fisht }\end{array}$} & \multirow{2}{*}{$\begin{array}{l}\text { Crude } \\
\text { mean }\end{array}$} & \multicolumn{2}{|c|}{ Adjusted } & \multirow{2}{*}{$\begin{array}{l}\% \text { Fatty } \\
\text { fish } \neq\end{array}$} & \multirow{2}{*}{$\begin{array}{l}\text { Crude } \\
\text { mean }\end{array}$} & \multicolumn{2}{|c|}{ Adjusted } & \multirow{2}{*}{$\begin{array}{l}\% \text { Fatty } \\
\text { fish } \neq\end{array}$} \\
\hline & & & Mean* & SE & & & Mean* & SE & & & Mean* & SE & \\
\hline Greece & 1374 & & & & & & & & & & & & \\
\hline Greece & 1374 & 8.9 & 9.0 & 1.0 & 28.0 & 6.5 & 6.8 & 0.8 & 73.0 & 2.4 & 2.2 & 0.6 & 27.0 \\
\hline Spain & 1443 & & & & & & & & & & & & \\
\hline Granada & 300 & 17.3 & 18.8 & 2.1 & 32.5 & 13.7 & 13.6 & 1.7 & 79.2 & 3.6 & 5.2 & 1.3 & 20.8 \\
\hline Murcia & 304 & 17.9 & 17.9 & 2.1 & 35.4 & 15.8 & 15.5 & 1.7 & 88.3 & 2.1 & 2.4 & 1.3 & 11.7 \\
\hline Navarra & 271 & 19.0 & 18.5 & 2.2 & 28.9 & 16.6 & 16.3 & 1.8 & 87.4 & 2.4 & 2.2 & 1.3 & 12.6 \\
\hline San Sebastian & 244 & 19.9 & 18.1 & 2.4 & 27.1 & 17.4 & 15.5 & 1.9 & 87.4 & 2.5 & 2.6 & 1.4 & 12.6 \\
\hline Asturias & 324 & 23.0 & 22.3 & 2.0 & 33.5 & 19.1 & 18.4 & 1.6 & 83.0 & 3.8 & 3.9 & 1.2 & 16.5 \\
\hline Italy & 2512 & & & & & & & & & & & & \\
\hline Ragusa & 138 & 14.7 & 17.1 & 3.1 & 47.9 & 11.5 & 14.0 & 2.5 & 78.2 & 3.3 & 3.1 & 1.9 & 22.4 \\
\hline Naples & 403 & 8.5 & 8.7 & 1.8 & 30.4 & 8.5 & 8.7 & 1.5 & 100.0 & 0.0 & 0.1 & 1.1 & 0.0 \\
\hline Florence & 785 & 6.5 & 6.6 & 1.3 & 32.8 & 6.0 & 6.1 & 1.1 & 92.3 & 0.6 & 0.5 & 0.8 & 9.2 \\
\hline Turin & 392 & 8.6 & 8.8 & 1.9 & 41.7 & 8.5 & 8.6 & 1.5 & 98.8 & 0.1 & 0.2 & 1.1 & 1.2 \\
\hline Varese & 794 & 9.8 & 8.8 & 1.3 & 49.2 & 9.5 & 8.5 & 1.0 & 96.9 & 0.3 & 0.2 & 0.8 & 3.1 \\
\hline France & 4639 & & & & & & & & & & & & \\
\hline South coast & 612 & 10.2 & 11.7 & 1.5 & 26.6 & 8.2 & 9.0 & 1.2 & 80.4 & 2.0 & 2.7 & 0.9 & 19.6 \\
\hline South & 1396 & 10.4 & 9.8 & 1.0 & 29.5 & 9.5 & 9.1 & 0.8 & 91.3 & 0.9 & 0.8 & 0.6 & 8.7 \\
\hline North-west & 622 & 11.8 & 11.4 & 1.5 & 23.3 & 9.9 & 9.9 & 1.2 & 83.9 & 1.9 & 1.5 & 0.9 & 16.1 \\
\hline North-east & 2009 & 11.1 & 11.2 & 0.8 & 30.0 & 9.4 & 9.7 & 0.7 & 84.7 & 1.7 & 1.6 & 0.5 & 15.3 \\
\hline Germany & 2150 & & & & & & & & & & & & \\
\hline Heidelberg & 1087 & 6.7 & 7.6 & 1.1 & 50.0 & 3.8 & 4.4 & 0.9 & 56.7 & 2.8 & 3.2 & 0.7 & 41.8 \\
\hline Potsdam & 1063 & 10.6 & 12.2 & 1.1 & 59.2 & 4.5 & 5.7 & 0.9 & 42.5 & 6.1 & 6.5 & 0.7 & 57.5 \\
\hline The Netherlands & 2960 & & & & & & & & & & & & \\
\hline Bilthoven & 1086 & 5.9 & 6.2 & 1.1 & 46.8 & 3.4 & 3.4 & 0.9 & 57.6 & 2.5 & 2.8 & 0.7 & 42.4 \\
\hline Utrecht & 1874 & 7.0 & 6.3 & 0.9 & 47.3 & 4.5 & 4.3 & 0.7 & 64.3 & 2.5 & 2.0 & 0.5 & 35.7 \\
\hline United Kingdom & 768 & & & & & & & & & & & & \\
\hline General population & 571 & 10.0 & 10.0 & 1.5 & 35.3 & 8.6 & 8.6 & 1.2 & 86.0 & 1.4 & 1.4 & 0.9 & 14.0 \\
\hline 'Health-conscious' & 197 & 8.6 & 7.3 & 2.6 & 54.4 & 7.4 & 6.0 & 2.1 & 86.0 & 1.2 & 1.4 & 1.6 & 14.0 \\
\hline Denmark & 1995 & & & & & & & & & & & & \\
\hline Copenhagen & 1485 & 17.0 & 17.7 & 1.0 & 45.4 & 6.2 & 6.6 & 0.8 & 36.5 & 10.7 & 11.1 & 0.6 & 62.9 \\
\hline Aarhus & 510 & 15.8 & 15.9 & 1.6 & 50.3 & 5.0 & 4.8 & 1.3 & 31.6 & 10.8 & 11.1 & 1.0 & 68.4 \\
\hline Sweden & 3285 & & & & & & & & & & & & \\
\hline Malmö & 1711 & 14.8 & 14.3 & 0.9 & 43.8 & 7.7 & 7.5 & 0.7 & 52.0 & 7.1 & 6.8 & 0.5 & 48.0 \\
\hline Umeå & 1574 & 15.0 & 13.8 & 0.9 & 52.1 & 8.0 & 7.2 & 0.7 & 53.3 & 7.0 & 6.6 & 0.6 & 46.7 \\
\hline Norway & 1798 & & & & & & & & & & & & \\
\hline South \& East & 1136 & 14.1 & 14.6 & 1.1 & 34.2 & 8.0 & 7.9 & 0.9 & 56.7 & 6.1 & 6.7 & 0.7 & 43.3 \\
\hline North \& West & 662 & 15.9 & 16.5 & 1.4 & 26.0 & 9.4 & 9.8 & 1.2 & 59.1 & 6.5 & 6.8 & 0.9 & 40.9 \\
\hline
\end{tabular}

SE - standard error.

${ }^{*}$ Adjusted for age, weighted for season and day of the week.

†Percentage of all fish and fish products (crude mean).

$\ddagger$ Percentage of all fatty fish.

than that of white fish: $10.9 \%$ for women, $10.5 \%$ for men (Tables 1a and 1b). In women, the greatest consumption was in North-west France (10.9 $\mathrm{g} \mathrm{day}^{-1}$ ) and was generally higher in the French, Spanish and Italian centres than in the British, German, Swedish, Danish or Norwegian centres. Although men consumed more crustacea, patterns of consumption followed those of women.

Consumption of total fatty fish reflected geographical patterns of total fish consumption and varied by a factor of 3.9 in women and 13.7 in men (see Tables $2 \mathrm{a}$ and 2b). Centres in Denmark, Germany, The Netherlands, Sweden and the Italian centres of Varese, Ragusa and Turin consumed more than $40 \%$ of fish as fatty fish. In the northern European countries, the percentage of very fatty fish eaten was greater than in the southern European countries.
The highest consumption of fish products was in the Danish and Norwegian centres and the lowest in the Italian and Greek centres (Tables $3 \mathrm{a}$ and $3 \mathrm{~b}$ ). The percentage of white fish-based products ranged from 0 to $100 \%$. Those centres where consumption of white fishbased products predominated were largely in France, Italy, Spain, The Netherlands and Norway. Regional variations showed that less than $60 \%$ of fish products contained white fish in the German, Swedish, Danish and Greek centres. Fish products in these areas were based on roe, fatty or very fatty fish. Consumption of roe-based products was generally low, with a maximum reported in Copenhagen (Denmark) of $2.3 \mathrm{~g}$ in women and $2.6 \mathrm{~g}$ in men.

The contribution in $\mathrm{g} \mathrm{day}^{-1}$ of different fish sub-groups to total daily fish intake is shown in Figs $2 \mathrm{a}$ and $2 \mathrm{~b}$. 
Table $\mathbf{2 b}$ Mean daily intake $\left(\mathrm{g} \mathrm{day}^{-1}\right)$ of total fatty fish, fatty fish and very fatty fish in men

\begin{tabular}{|c|c|c|c|c|c|c|c|c|c|c|c|c|c|}
\hline \multirow[b]{3}{*}{ Country and centre } & \multirow[b]{3}{*}{$n$} & \multicolumn{4}{|c|}{ Total fatty fish } & \multicolumn{4}{|c|}{ Fatty fish } & \multicolumn{4}{|c|}{ Very fatty fish } \\
\hline & & \multirow{2}{*}{$\begin{array}{l}\text { Crude } \\
\text { mean }\end{array}$} & \multicolumn{2}{|c|}{ Adjusted } & \multirow{2}{*}{$\begin{array}{l}\% \text { Fatty } \\
\text { fish† }\end{array}$} & \multirow{2}{*}{$\begin{array}{l}\text { Crude } \\
\text { mean }\end{array}$} & \multicolumn{2}{|c|}{ Adjusted } & \multirow{2}{*}{$\begin{array}{c}\% \text { Fatty } \\
\text { fish } \ddagger\end{array}$} & \multirow{2}{*}{$\begin{array}{l}\text { Crude } \\
\text { mean }\end{array}$} & \multicolumn{2}{|c|}{ Adjusted } & \multirow{2}{*}{$\begin{array}{c}\% \text { Fatty } \\
\text { fish } \ddagger\end{array}$} \\
\hline & & & Mean* & SE & & & Mean* & SE & & & Mean* & SE & \\
\hline Greece & 1312 & & & & & & & & & & & & \\
\hline Greece & 1312 & 16.4 & 18.9 & 1.4 & 35.7 & 12.1 & 13.1 & 1.1 & 73.8 & 4.3 & 5.8 & 0.9 & 26.2 \\
\hline Spain & 1777 & & & & & & & & & & & & \\
\hline Granada & 214 & 23.1 & 23.0 & 3.4 & 26.5 & 21.4 & 21.7 & 2.7 & 92.6 & 1.7 & 1.3 & 2.1 & 7.4 \\
\hline Murcia & 243 & 23.1 & 23.4 & 3.2 & 33.0 & 20.5 & 20.8 & 2.5 & 88.7 & 2.6 & 2.6 & 2.0 & 11.3 \\
\hline Navarra & 444 & 27.6 & 27.3 & 2.4 & 32.8 & 26.3 & 25.9 & 1.9 & 95.3 & 1.3 & 1.4 & 1.5 & 4.7 \\
\hline San Sebastian & 490 & 34.0 & 32.1 & 2.3 & 28.0 & 29.7 & 26.7 & 1.8 & 87.4 & 4.4 & 5.4 & 1.4 & 12.9 \\
\hline Asturias & 386 & 41.1 & 42.6 & 2.5 & 39.4 & 36.5 & 37.8 & 2.0 & 88.8 & 4.6 & 4.8 & 1.6 & 11.2 \\
\hline Italy & 1444 & & & & & & & & & & & & \\
\hline Ragusa & 168 & 11.6 & 9.5 & 3.9 & 34.0 & 11.0 & 8.9 & 3.0 & 94.8 & 0.7 & 0.6 & 2.4 & 6.0 \\
\hline Florence & 271 & 12.1 & 11.0 & 3.0 & 34.3 & 11.8 & 10.6 & 2.4 & 97.5 & 0.3 & 0.3 & 1.9 & 2.5 \\
\hline Turin & 677 & 15.4 & 15.9 & 1.9 & 44.4 & 15.1 & 15.5 & 1.5 & 98.1 & 0.4 & 0.4 & 1.2 & 2.6 \\
\hline Varese & 328 & 12.0 & 9.2 & 2.8 & 46.9 & 11.3 & 8.9 & 2.2 & 94.2 & 0.7 & 0.2 & 1.7 & 5.8 \\
\hline Germany & 2268 & & & & & & & & & & & & \\
\hline Heidelberg & 1033 & 9.9 & 10.6 & 1.6 & 61.5 & 6.1 & 6.6 & 1.2 & 61.6 & 3.9 & 4.0 & 1.0 & 39.4 \\
\hline Potsdam & 1235 & 16.6 & 17.1 & 1.4 & 70.0 & 6.5 & 6.7 & 1.1 & 39.2 & 10.1 & 10.4 & 0.9 & 60.8 \\
\hline The Netherlands & 1024 & & & & & & & & & & & & \\
\hline Bilthoven & 1024 & 8.2 & 8.0 & 1.6 & 45.8 & 4.7 & 4.4 & 1.3 & 57.3 & 3.6 & 3.6 & 1.0 & 43.9 \\
\hline United Kingdom & 518 & & & & & & & & & & & & \\
\hline General population & 404 & 14.5 & 14.0 & 2.5 & 42.9 & 10.6 & 10.7 & 2.0 & 73.1 & 3.8 & 3.3 & 1.5 & 26.2 \\
\hline 'Health-conscious' & 114 & 3.0 & 4.0 & 4.7 & 46.9 & 3.0 & 3.9 & 3.7 & 100.0 & 0.0 & 0.1 & 2.9 & 0.0 \\
\hline Denmark & 1923 & & & & & & & & & & & & \\
\hline Copenhagen & 1356 & 23.0 & 22.9 & 1.4 & 48.3 & 8.9 & 8.7 & 1.1 & 38.7 & 14.0 & 14.2 & 0.8 & 60.9 \\
\hline Aarhus & 567 & 21.6 & 21.8 & 2.1 & 48.6 & 6.5 & 6.3 & 1.7 & 30.1 & 15.1 & 15.5 & 1.3 & 69.9 \\
\hline Sweden & 2765 & & & & & & & & & & & & \\
\hline Malmö & 1421 & 17.3 & 16.1 & 1.4 & 41.3 & 7.2 & 6.6 & 1.1 & 41.6 & 10.1 & 9.5 & 0.9 & 58.4 \\
\hline Umeå & 1344 & 18.5 & 17.5 & 1.4 & 54.4 & 9.6 & 9.3 & 1.1 & 51.9 & 8.8 & 8.2 & 0.8 & 47.6 \\
\hline
\end{tabular}

SE - standard error.

${ }^{*}$ Adjusted for age, weighted for season and day of the week.

$\dagger$ Percentage of all fish and fish products (crude mean).

$\ddagger$ Percentage of all fatty fish.

\section{Types offish}

Table 4 illustrates consumption of the types of fish that contribute to $90 \%$ of intake. The number of types of fish reported varied between 16 in the UK general population and 33 in France.

Overall, the seven fish consumed most commonly, representing $70 \%$ of intake of the whole cohort, were cod (18.7\%), herring (12.8\%), salmon (11.0\%), hake/burbot (9.9\%), tuna (8.4\%), mackerel (5.7\%) and trout (3.6\%). Besides Spain, the only country that reported hake/burbot in substantial amounts was France. Bass and mullet were reported in Italy, France, Spain and Greece but not in centres in northern Europe. Other fish reported by southern European countries only were swordfish, reported in Italy (2.8\%), Spain (0.5\%) and Greece (0.6\%); and shark in Italy (1.4\%), France (1.4\%) and Spain (0.8\%). Gilthead was consumed in Greece and Italy. Red fish was reported only in Norway (2.4\%) and Denmark (0.4\%).

\section{Days of the week}

There is day-to-day variability in fish consumption in both men and women (Figs $3 \mathrm{a}$ and 3b). For men, the highest intake was on a Friday in Spain, the UK general population, Italy, Germany and The Netherlands. Intake in Greece and Sweden was highest on Tuesdays. In Denmark, the highest intake was on Saturday. In women, Friday predominated as the day of highest consumption in France, the UK general population and Italy, whereas Saturday predominated in Spain, Denmark, Sweden, Greece and The Netherlands. In Norway, intake was higher between Monday and Thursday than on the remaining days of the week.

The centres in France, Italy, Spain, Germany, the UK and The Netherlands, where Friday predominated as the day of greater or maximum consumption, are those where the tradition of fish consumption instead of meat on this day has existed, largely for religious reasons.

Generally, the centres in countries that consume the most fish, i.e. Spain, Norway, France, Greece, Denmark and Sweden, exhibit the smallest day-to-day variation in consumption, with a coefficient of variation around $30 \%$ or below (data not shown), indicating that countries consuming the most fish also consume it more frequently. Conversely, those countries where fish consumption is lower (the UK, Italy, Germany and The Netherlands) have greater daily variability in fish consumption and a coefficient of variation of up to $50.6 \%$ (men in The Netherlands). 
Table 3a Mean daily intake $\left(\mathrm{g} \mathrm{day}^{-1}\right)$ and percentages of fish products in women

\begin{tabular}{|c|c|c|c|c|c|c|c|c|}
\hline \multirow[b]{3}{*}{ Country and centre } & \multirow[b]{3}{*}{$n$} & \multicolumn{4}{|c|}{ Fish products } & \multirow{3}{*}{$\begin{array}{l}\% \text { White fish } \\
\text { products } ¥\end{array}$} & \multirow{3}{*}{$\begin{array}{l}\% \text { Fatty fish } \\
\text { products } \ddagger\end{array}$} & \multirow{3}{*}{$\begin{array}{c}\% \text { Roe } \\
\text { products } \ddagger\end{array}$} \\
\hline & & \multirow{2}{*}{$\begin{array}{l}\text { Crude } \\
\text { mean }\end{array}$} & \multicolumn{2}{|c|}{ Adjusted } & \multirow{2}{*}{$\begin{array}{c}\% \text { Fish } \\
\text { products† }\end{array}$} & & & \\
\hline & & & Mean* & SE & & & & \\
\hline Greece & 1374 & & & & & & & \\
\hline Greece & 1374 & 0.6 & 0.5 & 0.7 & 1.9 & 0.0 & 0.0 & 100.0 \\
\hline Spain & 1443 & & & & & & & \\
\hline Granada & 300 & 1.0 & 1.2 & 1.4 & 1.9 & 100.0 & 0.0 & 0.0 \\
\hline Murcia & 304 & 2.9 & 2.8 & 1.4 & 5.7 & 93.1 & 0.0 & 6.9 \\
\hline Navarra & 271 & 1.7 & 2.0 & 1.5 & 2.6 & 100.0 & 0.0 & 0.0 \\
\hline San Sebastian & 244 & 1.3 & 1.2 & 1.6 & 1.8 & 76.9 & 0.0 & 23.1 \\
\hline Asturias & 324 & 1.2 & 1.3 & 1.3 & 1.8 & 83.3 & 16.7 & 0.0 \\
\hline Italy & 2512 & & & & & & & \\
\hline Ragusa & 138 & 0.0 & 0.0 & 2.1 & 0.0 & 0.0 & 100.0 & \\
\hline Naples & 403 & 0.6 & 0.3 & 1.2 & 2.1 & 100.0 & 0.0 & 0.0 \\
\hline Florence & 785 & 0.4 & 0.3 & 0.9 & 2.0 & 100.0 & 0.0 & 0.0 \\
\hline Turin & 392 & 0.3 & 0.3 & 1.2 & 1.5 & 66.7 & 33.3 & 0.0 \\
\hline Varese & 794 & 0.3 & 0.3 & 0.9 & 1.5 & 100.0 & 0.0 & 0.0 \\
\hline France & 4639 & & & & & & & \\
\hline South coast & 612 & 2.6 & 2.6 & 1.0 & 6.8 & 84.6 & 3.9 & 11.5 \\
\hline South & 1396 & 2.7 & 2.8 & 0.7 & 7.6 & 96.3 & 0.0 & 3.7 \\
\hline North-west & 622 & 2.3 & 2.4 & 1.0 & 4.5 & 82.6 & 17.4 & 0.0 \\
\hline North-east & 2009 & 2.5 & 2.7 & 0.5 & 6.8 & 80.0 & 8.0 & 12.0 \\
\hline Germany & 2150 & & & & & & & \\
\hline Heidelberg & 1087 & 3.4 & 3.8 & 0.7 & 25.8 & 47.1 & 52.9 & 0.0 \\
\hline Potsdam & 1063 & 4.8 & 4.8 & 0.7 & 26.8 & 29.2 & 70.8 & 0.0 \\
\hline The Netherlands & 2960 & & & & & & & \\
\hline Bilthoven & 1086 & 1.8 & 1.8 & 0.8 & 14.3 & 94.4 & 5.6 & 0.0 \\
\hline Utrecht & 1874 & 2.7 & 2.6 & 0.6 & 18.2 & 96.3 & 3.7 & 0.0 \\
\hline United Kingdom & 768 & & & & & & & \\
\hline General population & 571 & 3.7 & 3.5 & 1.0 & 13.1 & 73.0 & 16.2 & 10.8 \\
\hline 'Health-conscious' & 197 & 0.3 & 0.4 & 1.7 & 1.9 & 0.0 & 33.3 & 66.7 \\
\hline Denmark & 1995 & & & & & & & \\
\hline Copenhagen & 1485 & 13.7 & 13.9 & 0.6 & 36.8 & 54.7 & 28.5 & 16.8 \\
\hline Aarhus & 510 & 12.9 & 12.7 & 1.1 & 41.1 & 38.0 & 50.4 & 11.6 \\
\hline Sweden & 3285 & & & & & & & \\
\hline Malmö & 1711 & 3.6 & 3.5 & 0.6 & 10.7 & 58.3 & 13.9 & 27.8 \\
\hline Umeå & 1574 & 5.0 & 4.6 & 0.6 & 17.4 & 36.0 & 36.0 & 28.0 \\
\hline Norway & 1798 & & & & & & & \\
\hline South \& East & 1136 & 12.6 & 12.4 & 0.7 & 30.6 & 88.9 & 2.4 & 8.7 \\
\hline North \& West & 662 & 20.2 & 21.2 & 1.0 & 33.1 & 92.6 & 0.0 & 7.4 \\
\hline
\end{tabular}

SE - standard error.

${ }^{*}$ Adjusted for age, weighted for season and day of the week.

†Percentage of all fish and fish products (crude mean).

$\ddagger$ Percentage of fish products.

\section{Discussion}

We have found that fish intake varies greatly throughout Europe, by a factor of 6 in women and more than 7 in men, with the highest consumption in centres in Spain and the lowest in centres in Germany. Fish consumption is generally higher in areas with greater coastal access, reflecting traditional patterns of consumption and early distribution gradients related to the short shelf life of fresh fish $^{34}$

Intake of fish products is greater in northern than in southern Europe. As a percentage of total fish consumption, intake of fatty fish is greater in the coastal areas of northern Europe (Denmark, Sweden) and in Germany than in central and southern Europe.

A greater number of fish types were consumed in southern than in northern Europe and may reflect the fact that fewer species are available in colder northern waters $^{34}$. It may also reflect traditional and cultural influences on the acceptability of different species of fish for consumption.

The detailed design and data collection of this study contrasts with many other studies and has enabled the investigation of sub-groups and fish types. The data were collected by one method in all centres, standardised for the software, databases, interviewing techniques and subsequent treatment of the data. This means that the data are unique in terms of their ability to provide the European comparisons shown here. However, there are limitations to the use of 24-hour recalls in classifying individuals with respect to habitual intake, due to day-to-day variability ${ }^{38}$. This is particularly the case for fish, which is usually eaten only once or twice in any day and often less than once a week. This study was designed to establish intake within a 
Table 3b Mean daily intake $\left(\mathrm{g} \mathrm{day}^{-1}\right)$ and percentages of fish products in men

\begin{tabular}{|c|c|c|c|c|c|c|c|c|}
\hline \multirow[b]{3}{*}{ Country and centre } & \multirow[b]{3}{*}{$n$} & \multicolumn{4}{|c|}{ Fish products } & \multirow{3}{*}{$\begin{array}{l}\% \text { White fish } \\
\text { products } \neq\end{array}$} & \multirow{3}{*}{$\begin{array}{l}\% \text { Fatty fish } \\
\text { products } \ddagger\end{array}$} & \multirow{3}{*}{$\begin{array}{c}\% \text { Roe } \\
\text { products } \ddagger\end{array}$} \\
\hline & & \multirow{2}{*}{$\begin{array}{l}\text { Crude } \\
\text { mean }\end{array}$} & \multicolumn{2}{|c|}{ Adjusted } & \multirow{2}{*}{$\begin{array}{l}\% \text { Fish } \\
\text { products† }\end{array}$} & & & \\
\hline & & & Mean* & SE & & & & \\
\hline Greece & 1312 & & & & & & & \\
\hline Greece & 1312 & 0.6 & 0.4 & 0.7 & 1.3 & 16.7 & 16.6 & 66.7 \\
\hline Spain & 1777 & & & & & & & \\
\hline Granada & 214 & 1.2 & 1.4 & 1.8 & 1.4 & 75.0 & 8.3 & 16.7 \\
\hline Murcia & 243 & 3.7 & 3.2 & 1.7 & 5.3 & 78.4 & 0.0 & 21.6 \\
\hline Navarra & 444 & 1.1 & 1.2 & 1.2 & 1.3 & 100.0 & 0.0 & 0.0 \\
\hline San Sebastian & 490 & 2.6 & 2.6 & 1.2 & 2.1 & 100.0 & 0.0 & 0.0 \\
\hline Asturias & 386 & 0.6 & 0.5 & 1.3 & 0.6 & 100.0 & 0.0 & 0.0 \\
\hline Italy & 1444 & & & & & & & \\
\hline Ragusa & 168 & 0.6 & 0.7 & 2.0 & 1.8 & 100.0 & 0.0 & 0.0 \\
\hline Florence & 271 & 0.1 & 0.1 & 1.6 & 0.3 & 100.0 & 0.0 & 0.0 \\
\hline Turin & 677 & 1.5 & 1.3 & 1.0 & 4.3 & 93.3 & 6.7 & 0.0 \\
\hline Varese & 328 & 0.8 & 0.6 & 1.4 & 3.1 & 100.0 & 0.0 & 0.0 \\
\hline Germany & 2268 & & & & & & & \\
\hline Heidelberg & 1033 & 2.4 & 2.1 & 0.8 & 14.9 & 37.5 & 62.5 & 0.0 \\
\hline Potsdam & 1235 & 6.1 & 6.3 & 0.7 & 25.7 & 14.8 & 83.6 & 1.6 \\
\hline The Netherlands & 1024 & & & & & & & \\
\hline Bilthoven & 1024 & 4.1 & 4.2 & 0.8 & 22.9 & 95.1 & 4.9 & 0.0 \\
\hline United Kingdom & 518 & & & & & & & \\
\hline General population & 404 & 4.8 & 5.4 & 1.3 & 14.2 & 68.8 & 31.3 & 0.0 \\
\hline 'Health-conscious' & 114 & 1.0 & 0.9 & 2.5 & 15.6 & 100.0 & 0.0 & 0.0 \\
\hline Denmark & 1923 & & & & & & & \\
\hline Copenhagen & 1356 & 18.2 & 18.0 & 0.7 & 38.2 & 47.3 & 36.8 & 15.9 \\
\hline Aarhus & 567 & 18.2 & 18.1 & 1.1 & 41.0 & 47.8 & 42.3 & 9.9 \\
\hline Sweden & 2765 & & & & & & & \\
\hline Malmö & 1421 & 4.7 & 4.8 & 0.7 & 11.2 & 57.4 & 10.6 & 31.9 \\
\hline Umeå & 1344 & 5.1 & 4.4 & 0.7 & 15.1 & 29.4 & 33.3 & 37.3 \\
\hline
\end{tabular}

SE - standard error.

${ }^{*}$ Adjusted for age, weighted for season and day of the week. $\dagger$ Percentage of all fish and fish products (crude mean). $\ddagger$ Percentage of fish products.

representative sample of the population groups in the main EPIC study and, in the main, an equal number of days of the week and seasons were sampled over the period of 1 year. The distribution of fish intake was skewed in most countries and included more than $50 \%$ of zero values, rendering the median value uninformative. In an analysis of individual fish reporters, there was little variation in the mean intake between countries and presentation of these data would not have met the objective of the study. As the goal was to investigate variability between countries, the mean intake is presented and can be interpreted as a summary indicator combining the population frequency of consumption and the quantity consumed by fish reporters. Additionally, a supporting paper has concluded that, 'after adjustment for age, the calibration samples are fairly representative of the entire group of cohorts and that dietary intakes estimated from these sub-samples should reasonably be interpreted as representative of the main cohorts in most of the EPIC centres $^{31}$.

Relatively few data are available for comparison of fish intake between countries. However, those that do exist are in broad agreement with the relative ranking of consumption by country found by this study. FAO statistics for availability of all fish and marine foods (supply per capita per year in kilograms) show the following order: Norway (50.1), Spain (40.9), France (28.7), Sweden (27.5), Greece (26.7), Denmark (24.4), Italy (23.5), the UK (22.1), The Netherlands (15.9) and Germany (14.6) ${ }^{35}$. Data from the DAFNE (DAta Food NEtworking) study based on household budget surveys, which include waste material, provide figures for average consumption of $75 \mathrm{~g} \mathrm{day}^{-1}$ in Spain, $53 \mathrm{~g} \mathrm{day}^{-1}$ in Norway, $38 \mathrm{~g} \mathrm{day}^{-1}$ in Greece, $21 \mathrm{~g} \mathrm{day}^{-1}$ in the UK and $12 \mathrm{~g} \mathrm{day}^{-1}$ in Germany ${ }^{36}$. The SENECA (Survey in Europe on Nutrition and the Elderly: a Concerted Action) study of the elderly, aged between 74 and 79 years, using weighed records, found average daily intakes of fish of $119 \mathrm{~g}$ in Spain, $21 \mathrm{~g}$ in Denmark and $12 \mathrm{~g}$ in The Netherlands ${ }^{37}$.

The study of different sub-groups of fish is important to avoid misclassification of $n-3$ PUFA and for a better understanding of the aetiological mechanisms associating fish intake and disease. Judged by total fish consumption alone, it would be expected in this study that plasma levels of EPA and DHA would be higher in centres in Spain than in Denmark, as intake in Spain is almost twice that of Denmark. However, a sub-study of this population (excluding Norway) found substantial variation in plasma 

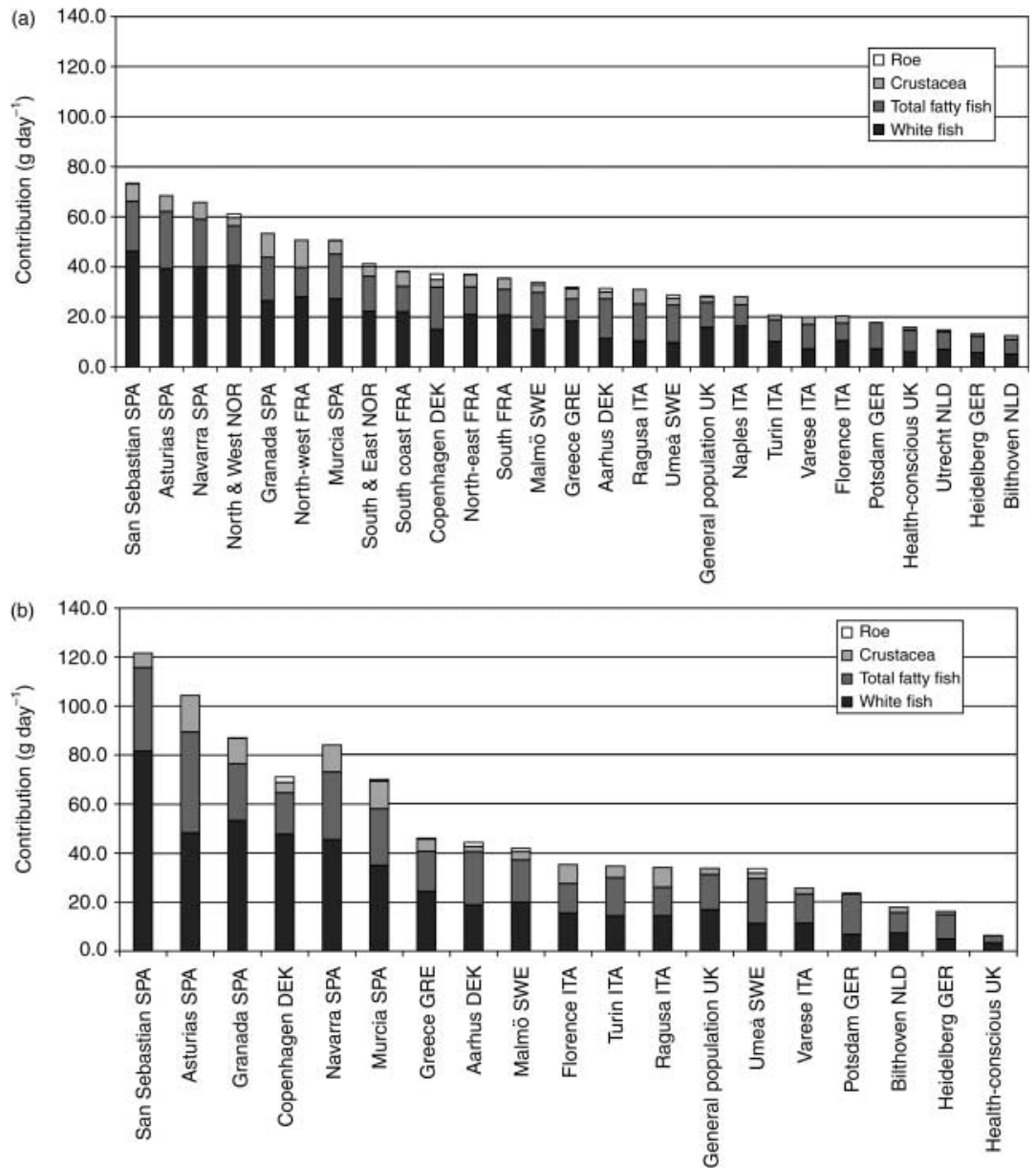

Fig. 2 Contribution of different fish sub-groups to total consumption of fish $\left(\mathrm{g} \mathrm{day}^{-1}\right)$ : (a) women in 27 centres; (b) men in 19 centres. Abbreviations: GRE - Greece; SPA - Spain; ITA - Italy; FRA - France; GER - Germany; NLD - The Netherlands; UK - United Kingdom; DEK - Denmark; SWE - Sweden; NOR - Norway

EPA and DHA, which largely reflected consumption of fatty fish (Saadatian-Elahi, in preparation). The lowest values of EPA and DHA were found in the Italian and Dutch centres and the highest values were found in Denmark, and not Spain, as was expected. This is because consumption of fatty fish in Denmark forms a higher percentage of total fish intake (48\%) than in Spain, where it is $32 \%$.

As well as total or average exposure to $n-3$ PUFA, it might be important to understand more about variability of exposure. We have found differences in the day-to-day variability in fish consumption between countries. Variability by day of the week was the greatest in countries with the lowest intake. The days of highest consumption were mainly Fridays and Saturdays. A number of traditional, cultural and economic reasons are responsible for this day-to-day variability. As described elsewhere, for practical reasons in some centres, fewer Fridays and Saturdays were recorded, particularly in the German centres where the number of Fridays was less than half that expected ${ }^{31}$. However, it is unlikely that this would bias or affect the amount of fish reported.
We would have liked to explore the differences in fish consumption by socio-economic and anthropometric classifications, but were unable to do so because it is not possible to classify habitual consumption of individuals or determine fish-eating status using a 24-hour recall.

The protective effect of fish for cancers of the breast, colon and other parts of the digestive system, reported since the WCRF/AICR and COMA reports, are likely to be due to the effects of $n-3$ PUFA. $n-3$ PUFA have been shown to reduce the production of eicosanoids or prostaglandins, enhance apoptosis and inhibit angiogenesis ${ }^{7,39,40}$.

A further mechanism for disease protection may be the displacement of meat by fish as a component in main meals ${ }^{6}$. With only one day of recall available for each individual, we were unable to explore this association. Although the relationship between fish and meat consumption is important, the strength of the existing evidence and number of potential mechanisms indicate that the interaction of fish and disease warrants independent study.

We believe this is the first time that fish intake has been studied in such a detailed, standardised way in a large 


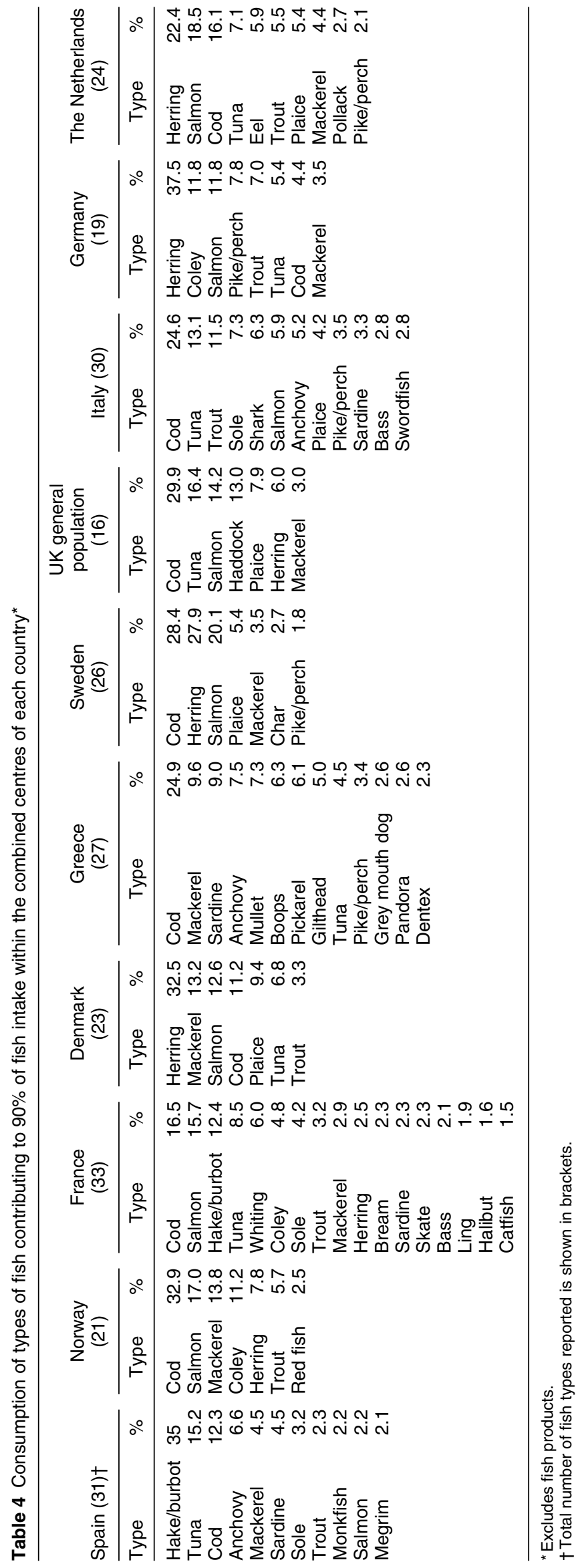



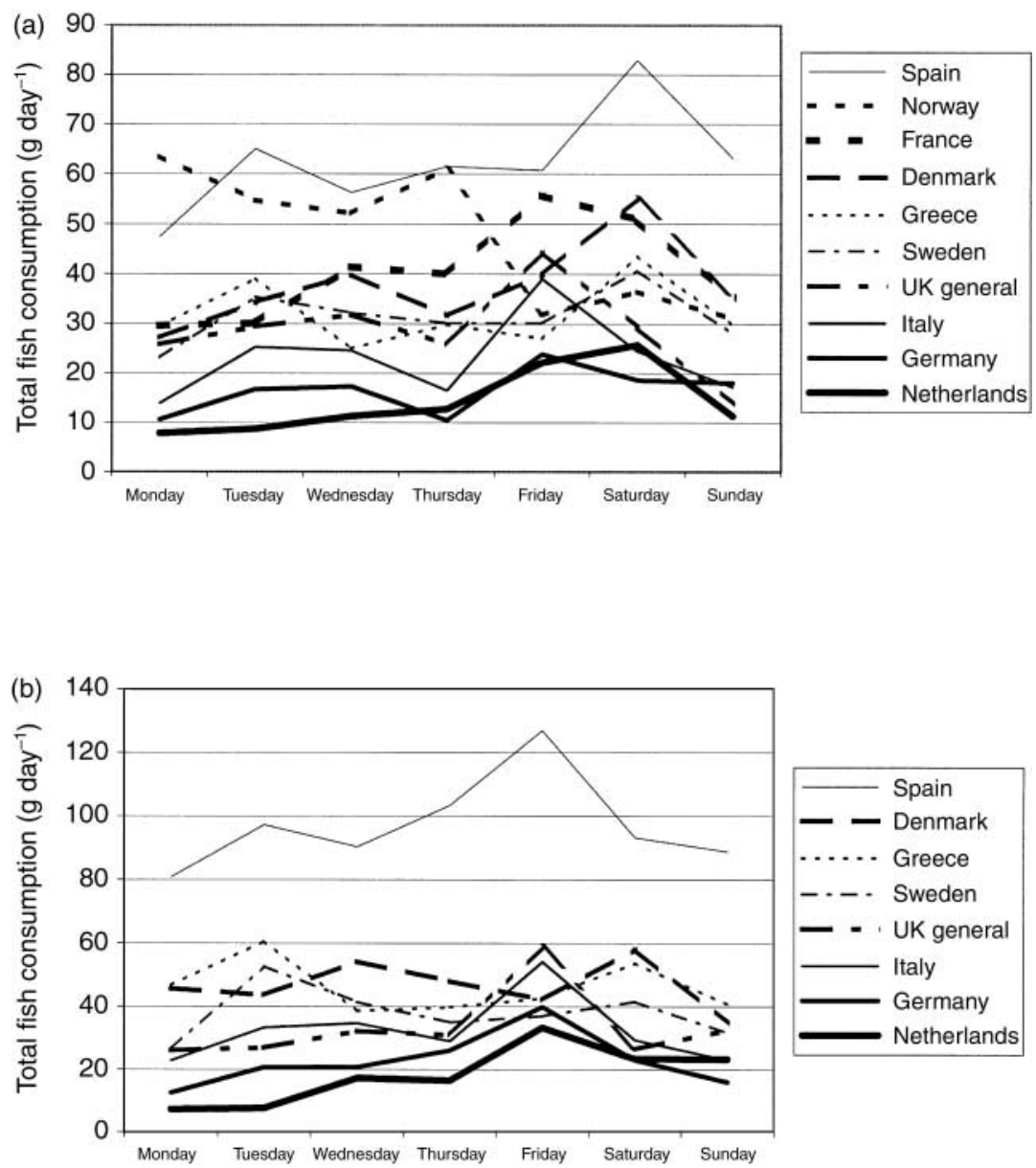

Fig. 3 Day-to-day variation in total fish consumption (g day ${ }^{-1}$ ): (a) women; (b) men

multi-centre population study in 10 European countries. This study of fish and its sub-groups forms the basis for further investigations into the relationship with cancer and other diseases within EPIC.

\section{Acknowledgements}

The work described in this paper was carried out with financial support of the 'Europe Against Cancer' Programme of the European Commission (SANCO); Ligue contre le Cancer (France); Société $3 \mathrm{M}$ (France); Mutuelle Générale de l'Education Nationale; Institut National de la Santé et de la Recherche Médicale (INSERM); Institute Gustave Roussy; German Cancer Aid; German Cancer Research Centre; German Federal Ministry of Education and Research; Danish Cancer Society; Health Research Fund (FIS) of the Spanish Ministry of Health; the Spanish Regional Governments of Andalucia, Asturias, Basque Country, Murcia and Navarra; Cancer Research UK; Medical Research Council, UK; Stroke Association, UK; British Heart Foundation; Department of Health, UK; Food Standards Agency, UK; Wellcome Trust, UK; Greek Ministry of Health; Greek Ministry of Education; Italian
Association for Research on Cancer; Italian National Research Council; Dutch Ministry of Public Health, Welfare and Sports; Dutch Prevention Funds; LK Research Funds; Dutch ZON (Zorg Onderzoek Nederland); World Cancer Research Fund; Swedish Cancer Society; Swedish Scientific Council; Regional Government of Skane, Sweden; Norwegian Cancer Society; Norwegian Research Council. Partial support for the publication of this supplement was provided by the Centre de Recherche et d'Information Nutritionnelles (CERIN).

In addition, we wish to thank all study participants for their co-operation and all interviewers who participated in the fieldwork studies in each EPIC centre.

\section{References}

1 World Cancer Research Fund (WCRF)/American Institute for Cancer Research (AICR). Food, Nutrition and the Prevention of Cancer: A Global Perspective. Washington, DC: WCRF/AICR, 1997.

2 UK Committee on Medical Aspects of Food and Nutrition (COMA). Nutritional Aspects of the Development of Cancer. Report on Health and Social Subjects No. 48. London: HMSO, 1998.

3 International Agency for Research on Cancer (IARC). Some 
Naturally Occurring Substances: Food Items and Constituents, Heterocyclic Amines and Mycotoxins. IARCMonographs on the Evaluation of Carcinogenic Risks of Chemicals to Humans. Vol. 56. Lyon, France: IARC, 1997.

4 Caygill CP, Charlett A, Hill MJ. Fat, fish, fish oil and cancer. Br. J. Cancer 1996; 74(1): 159-64.

5 Fernandez E, Chatenoud L, La Vecchia C, Negri E, Franceschi S. Fish consumption and cancer risk. Am.J. Clin. Nutr. 1999; 70(1): 85-90.

6 De Deckere EA. Possible beneficial effect of fish and fish $n-3$ polyunsaturated fatty acids in breast and colorectal cancer. Review. Eur. J. Cancer Prev. 1999; 8(3): 213-21.

7 Norrish AE, Skeaff CM, Arribas GL, Sharpe SJ, Jackson RT. Prostate cancer risk and consumption of fish oils: a dietary biomarker-based case-control study. Br. J. Cancer 1999; 81(7): 1238-42.

8 Terry P, Lichtenstein P, Feychting M, Ahlbom A, Wolk A. Fatty fish consumption and risk of prostate cancer. Lancet 2001; 357(9270): 1764-6.

9 Menotti A, Kromhout D, Blackburn H, Fidanza F, Buzina R, Nissinen A. Food intake patterns and 25-year mortality from coronary heart disease: cross-cultural correlations in the Seven Countries Study. The Seven Countries Study Research Group. Eur.J. Epidemiol. 1999; 15(6): 507-15.

10 Marckmann P, Gronbaek M. Fish consumption and coronary heart disease mortality. A systematic review of prospective cohort studies. Eur. J. Clin. Nutr. 1999; 53(8): 585-90.

11 Zhang J, Sasaki S, Amano K, Kesteloot H. Fish consumption and mortality from all causes, ischemic heart disease, and stroke: an ecological study. Prev. Med. 1999; 28(5): 520-9.

12 Oomen CM, Feskens EJ, Rasanen L, Fidanza F, Nissinen AM, Menotti A, et al. Fish consumption and coronary heart disease mortality in Finland, Italy, and The Netherlands. Am. J. Epidemiol. 2000; 151(10): 999-1006.

13 Schmidt EB, Skou HA, Christensen JH, Dyerberg J. $n-3$ Fatty acids from fish and coronary artery disease: implications for public health. Review. Public Health Nutr. 2000; 3(1): 91-8.

14 Nestel P. Fish oil and cardiovascular disease: lipids and arterial function. Am. J. Clin. Nutr. 2000; 71(1): 228-31.

15 Hallgren CG, Hallmans G, Jansson JH, Marklund SL, Huhtasaari F, Schutz A, et al. Markers of high fish intake are associated with decreased risk of a first myocardial infarction. Br. J. Nutr. 2001; 86(3): 397-404.

16 Connor WE. $n-3$ Fatty acids from fish and fish oil: panacea or nostrum? Am. J. Clin. Nutr. 2001; 74(4): 415-6.

17 Holland B, Brown J, Buss DH. Fish and Fish Products. Third Supplement to McCance \& Widdowson's The Composition of Foods, 5th ed. Cambridge: Royal Society of Chemistry, 1993.

18 Garrow JS, James WPT. Human Nutrition and Dietetics, 9th ed. Edinburgh: Churchill Livingstone, 1993.

19 Fatty Acids. Supplement to McCance \& Widdowson's The Composition of Foods. Cambridge: Royal Society of Chemistry/Ministry of Agriculture, Fisheries and Food, 1998.

20 Bønaa KH, Bjerve KS, Nordøy A. Habitual fish consumption, plasma phospholipid fatty acids, and serum lipids: The Tromsø Study. Am.J. Clin. Nutr. 1992; 55: 1126-34.

21 Svensson BG, Akesson B, Nilsson A, Skerfving S. Fatty acid composition of serum phosphatidylcholine in healthy subjects consuming varying amounts of fish. Eur. J. Clin. Nutr. 1993; 47(2): 132-40

22 Tjonneland A, Overvad K, Thorling E, Ewertz M. Adipose tissue fatty acids as biomarkers of dietary exposure in Danish men and women. Am. J. Clin. Nutr. 1993; 57(5): 629-33.

23 Marckmann P, Lassen A, Haraldsdottir J, Sandstrom B. Biomarkers of habitual fish intake in adipose tissue. $\mathrm{Am}$. J. Clin. Nutr. 1995; 62(5): 956-9.

24 Anttolainen M, Valsta LM, Alfthan G, Kleemola P, Salminen I,
Tamminen M. Effect of extreme fish consumption on dietary and plasma antioxidant levels and fatty acid composition. Eur. J. Clin. Nutr. 1996; 50(11): 741-6.

25 Ma J, Foldon AR, Shahar E, Eckfeldt JH. Plasma fatty acid composition as an indicator of habitual dietary fat intake in middle-aged adults. The Atherosclerosis Risk in Communities (ARIC) Study Investigators. Am. J. Clin. Nutr. 1995; 62: 564-71.

26 Andersen LF, Solvoll K, Drevon CA. Very-long-chain $n-3$ fatty acids as biomarkers for intake of fish and $n-3$ fatty acid concentrates. Am. J. Clin. Nutr. 1996; 64(3): 305-11.

27 Hjartaker A, Lund E, Bjerve KS. Serum phospholipid fatty acid composition and habitual intake of marine foods registered by a semi-quantitative food frequency questionnaire. Eur. J. Clin. Nutr. 1997; 51(11): 736-42.

28 Zock PL, Mensink RP, Harryvan J, de Vries JH, Katan MB. Fatty acids in serum cholesteryl esters as quantitative biomarkers of dietary intake in humans. Am. J. Epidemiol. 1997; 145(12): 1114-22.

29 Amiano P, Dorronsoro M, de Renobales M, Ruiz de Gordoa JC, Iriogien I. Very long chain $\omega-3$ fatty acids as markers for habitual fish intake in a population consuming mainly lean fish: the EPIC cohort of Gipuzkoa. Eur. J. Clin. Nutr. 2001; 55(10): 827-32.

30 Riboli E, Hunt KJ, Slimani N, Ferrari P, Norat T, Fahey M, et al. European Investigation into Cancer and Nutrition (EPIC): study populations and data collection. Public Health Nutr. 2002; 5(6B): 1113-24.

31 Slimani N, Kaaks R, Ferrari P, Casagrande C, Clavel-Chapelon $\mathrm{F}$, Lotze $\mathrm{G}$, et al. European Investigation into Cancer and Nutrition (EPIC) calibration study: rationale, design and population characteristics. Public Health Nutr. 2002; 5(6B): $1125-45$.

32 Slimani N, Deharveng G, Charrondière RU, van Kappel AL, Ocké MC, Welch A, et al. Structure of the standardized computerized 24-hour diet recall interview used as a reference method in the 22 centers participating in the EPIC project. Comput. Meth. Programs Biomed. 1999; 58 : 251-66.

33 Slimani N, Ferrari P, Ocké MC, Welch A, Boeing H, van Liere $\mathrm{M}$, et al. Standardization of the 24-hour diet recall calibration method used in the European Prospective Investigation into Cancer and Nutrition (EPIC): general concepts and preliminary results. Eur. J. Clin. Nutr. 2000; 54: 900-17.

34 Ruiter A. Fish and Fishery Products. Composition, Nutritive Properties and Stability. Wallingford, UK: CAB International, 1995.

35 FAOSTAT - Statistical databases online statistics for fish, seafood supply, 1999. Available at http.//www.fa.org.

36 Byrd-Bredbenner C, Lagiou P, Trichopolou A. A comparison of household food availability in 11 countries. J. Hum. Nutr. Diet. 2000; 13: 197-204.

37 Schroll K, Moreiras-Varela O, Schlettwein-Gsell D, Decarli B, de Groot L, van Staveren W. Cross-cultural variations and changes in food-group intake among elderly women in Europe: results from the Survey in Europe on Nutrition and the Elderly: a Concerted Action (SENECA). Am. J. Clin. Nutr. 1997; 65(Suppl.): 1282S-9S.

38 Bingham SA, Nelson M. Assessment of food composition and nutrient intake. In: Margetts BM, Nelson M, eds. Design Concepts in Nutritional Epidemiology. Oxford: Oxford University Press, 1991; 153-91.

39 Rose DP, Connolly JM. Regulation of tumor angiogenesis by dietary fatty acids and eicosanoids. Nutr. Cancer 2000; 37(2): $119-27$.

40 Rao CV, Hirose Y, Indranie C, Reddy BS. Modulation of experimental colon tumorigenesis by types and amounts of dietary fatty acids. Cancer Res. 2001; 61(5): 1927-33. 